\title{
Variability Chlorophyll-a And Sea Surface Temperature As The Fishing Ground Basis Of Mackerel Fish In The Arafura Sea
}

\author{
Marius Agustinus Welliken ${ }^{1 *}$,Edy H.P Melmambessy ${ }^{1}$, Sendy Lely Merly ${ }^{1}$, Rosa Delima Pangaribuan ${ }^{1}$, Bony Lantang ${ }^{1}$, \\ Johannes Hutabarat ${ }^{2}$ and Anindya Wirasatriya ${ }^{3,4}$ \\ ${ }^{1}$ Departement Management of Aquatic Resource, Agriculture of Faculty, Musamus University, Merauke - Indonesia \\ ${ }^{2}$ Department Aquatic, Faculty of Fisheries and Marine, Diponegoro University, Semarang - Indonesia \\ ${ }^{3}$ Departemen of Oceanography, Faculty of Fisheries and Marine, Diponegoro University, Semarang - Indonesia \\ ${ }^{4}$ Center for Disaster Mitigation and Coastal Rehabilition, Diponegoro University, Semarang - Indonesia
}

\begin{abstract}
Arafura Sea is one of the waters in the eastern region of Indonesia that is rich in marine and fisheries potentials because of its fertile conditions which is suitable for fishing ground. One of the fish resources which have important economic value at the Arafura Sea is big pelagic fish such as Mackerel. Thus this study aims to determine the spatial and temporal distribution of Mackerel in the Arafura Sea based on fishing boat coordinate data, to know the distribution of chlorophyll-a concentration and SST from MODIS satellite data in the Arafura Sea and to determine the correlation of chlorophyll-a and SST to the Mackerel catch distribution. This study was conducted in December 2016 until February 2017 in the Arafura Sea, image data analysis of MODIS level-3 conducted at the Laboratory of Oceanography FPIK UNDIP. The data used are Mackerel catch data, the Chlorophyll-a data and SST from MODIS satellite from June to August 2015. The results of this study showed that the distribution of Mackerel catch from June to August more were caught in August a total of 62.2 tons for 19 trips. While the chlorophyll-a between June and August ranged from 0.30 to $8.04 \mathrm{mg} / \mathrm{m}^{3}$ and SST in June-August ranged from $24.6{ }^{\circ} \mathrm{C}-28.4{ }^{\circ} \mathrm{C}$. The correlation between chlorophyll-a and Mackerel catch results showed very strong correlation (correlation coefficient (r) 0.934). While the correlation between SST with the Mackerel catch showed a strong correlation (correlation coefficient (r) 0.664 ).
\end{abstract}

Keywords: Chlorophyll-a ; Sea Surface Temperature ; Satellite Data and Mackerel Catch

\section{INTRODUCTION}

Arafura Sea is one of the waters in the eastern region of Indonesia that is rich in marine and fisheries potentials because of its fertile condition which is suitable for fishing ground. The fertile waters in Arafura Sea is quite high as seen in the value of chlorophyll-a concentration, ranging around 0.412$18.490 \mathrm{mg} / \mathrm{m} 3$ with an average of $3.021 \mathrm{mg} / \mathrm{m} 3$ [1], and the value of sea surface temperature concentration around $25.45^{\circ} \mathrm{C}-30.76^{\circ} \mathrm{C}$ [2]. Additionally, the condition of Arafura Sea is suitable for fishing ground because of upwelling process that makes Arafura Sea fertile to support the fish resource availability $[1,2,3]$

One of the fish resources that have important economic value in Arafura Sea is big pelagic fish such as Mackerel. The average of Mackerel catch in Arafura Sea from 2014 to 2015 is 1,710 ton/year or $45.72 \%$ of the total of big pelagic catch (DKP Kabupaten Kepulauan Aru, 2016). It will result in the increased demand on Mackerel catch. The rise of exploitation of fish resources is a result of the demand (Sobari, 2010).

Also states that one of the ways that can be used to determine the fishing ground is by utilizing remote sensing. One of the remote sensing satellites that can detect chlorophyll-a and SPL is Aqua MODIS satellite (Moderate Resolution Imaging Spectroradiometer). (Putra et al. 2010).

According to [4] Hayes and Laevastu (1981), the distribution of pelagic fish including Mackerel is influenced by surrounding aquatic environment. This type of fish always looks for suitable environment for the body condition. If the fertile water can be detected, the fishing ground can be determined; fishes tend to migrate to the fertile water. It means that the Mackerel catch result is more influenced by the combination of two oceanographic variables, that is, sea surface temperature (SST) and chlorophyll-a. However, a research conducted by Kasim et al. (2014) has not shown strong pattern of distribution of parameter SPL as well as chlorophyll-a to the Mackerel catch; the Mackerel catch cannot directly be influenced by sea surface temperature and chlorophyll-a. Therefore, it is necessary to conduct a research on the distribution of chlorophyll-a concentration and sea surface temperature to find out the Mackerel fishing area. The importance of the information about the distribution of chlorophyll-a concentration and sea surface

* Corresponding author: mariuswelliken@gmail.com 
temperature can be used by fishermen to predict and to determine the area as well as the time of the high distribution of Mackerel.

Knowing the right fishing ground can optimize the Mackerel catch result, time efficiency, and reduction of fishing cost. This research aims to find out the spatial and temporal distribution of Mackerel in the Arafura Sea based on the fishing boat coordinate data, to know the distribution of

\section{RESEARCH METHOD}

\subsection{Place and Time of Research}

The research is conducted from December 2016 to February 2017 at the Arafura Sea at the coordinate of $133^{\circ}$ BT $-140^{\circ}$ BT and $5^{\circ}$ LS $-11^{\circ}$ LS. The secondary data of Mackerel catch is obtained from the existing data of fishing company (CV Bahari Aru Permai), Aru Islands of Maluku. The analysis of image data of MODIS level-3 uses Programming Software, while the chlorophyll-a concentration and SST are observed in the Laboratory of Oceanography FPIK UNDIP.

\subsection{Equipment and Material}

Equipment and material used in this research is presented in Table 1 and Table 2.

Table 1. Equipment

\begin{tabular}{|l|l|l|}
\hline No & Equipment & Function \\
\hline $\mathbf{1}$ & $\begin{array}{l}\text { Computer with } \\
\text { AMD rocessor }\end{array}$ & $\begin{array}{l}\text { To perform the entire data } \\
\text { processing and research } \\
\text { report }\end{array}$ \\
\hline $\mathbf{2}$ & $\begin{array}{l}\text { Software } \\
\text { WinSCP }\end{array}$ & $\begin{array}{l}\text { To download image data of } \\
\text { MODIS level-3 }\end{array}$ \\
\hline $\mathbf{3}$ & $\begin{array}{l}\text { Software } \\
\text { SeaDas 7.3.1 }\end{array}$ & $\begin{array}{l}\text { To transform data of } \\
\text { chlorophyll-a and SST }\end{array}$ \\
\hline $\mathbf{4}$ & $\begin{array}{l}\text { Microsoft } \\
\text { Excel 2013 } \\
\text { and SPSS 21 }\end{array}$ & $\begin{array}{l}\text { To analyze statistic data of } \\
\text { correlation and regression }\end{array}$ \\
\hline $\mathbf{5}$ & ArcMap 10.2 & $\begin{array}{l}\text { To map out the distribution of } \\
\text { chlorophyll-a and SST }\end{array}$ \\
\hline
\end{tabular}

Table 2. Data collected in research

\begin{tabular}{|l|l|}
\hline No & Materials \\
\hline 1 & $\begin{array}{l}\text { Chlorophyll-a and SPL data from MODIS level- } \\
3 \text { satellite daily image with resolution of } 4 \mathrm{x} 4 \\
\mathrm{~km}^{2} \text { from June to August 2015 }\end{array}$ \\
\hline 2 & $\begin{array}{l}\text { Position coordinate data of Mackerel fishing } \\
\text { ground from the log book of fishing boat owned } \\
\text { by CV. Bahari Aru Permai. }\end{array}$ \\
\hline 3 & $\begin{array}{l}\text { Mackerel yield that is caught using boat hand } \\
\text { line 25 GT owned by fishing company (CV. } \\
\text { Bahari Aru Permai) in the Arafura Sea from }\end{array}$ \\
\hline
\end{tabular}

June to August 2015.

\subsection{Data Analysis}

2.3.1 The Relationship of Chlorophyll-a and Sea Surface Temperature Towards the Mackerel Catch Result.

Polynomial regression analysis is used to know the releationship between independent variable and dependent variable. According to Padmaningrat (2017) [5], polynomial regression analysis can be used to know linear regression, while correlation analysis is used to see how far the relationship of oceanographic parameter (SST and chlorophyll-a) towards the amount of fish catch. Polynomial regression analysis according to Bender et al (2014) [6] can be presented on equation 1 below:

$Y=a_{0}+a_{1} x+a_{2} x^{2}$

Where:

$\mathrm{Y} \quad=$ the amount of Mackerel yield

$\mathrm{a}=$ constant

$\mathrm{X}$ = oceanographic parameter (chlorophyll-a and SST)

Perfect linear relationship occurs between $\mathrm{x}$ and $\mathrm{y}$ if $r=+1$ or -1 . If $r$ value is close to that value, then there is high correlation between those two variables. Meanwhile, if $r$ value is close to 0 , then there is low correlation between $\mathrm{x}$ and $\mathrm{y}$ value. The correlation analysis aims to know whether the level of relationship between variables is strong [6]. According to Bender et al (2014) [6], correlation analysis can be presented in the following equation 2 :

Is low correlation between $x$ and $y$ value. The correlation analysis aims to know whether the level of relationship between variables is strong (Bender et al. 2014) [6]. According to Bender et al (2014)[6], correlation analysis can be presented in the following equation 2 :

$r=\frac{n \sum X_{i} Y-\left(\sum X_{i}\right)(\Sigma Y)}{\sqrt{\left(n \sum X_{i}^{2}-\left(\sum X_{i}\right)^{2}\right]\left[n \Sigma Y_{i}^{2}-\left(\sum Y_{i}\right)^{2}\right]}}$

Where:

$r=$ correlation coefficient value

$n=$ the amount of catch data

$Y=$ the amount of Mackerel yield

$X=$ oceanographic parameter (sea surface temperature and chlorophyll-a)

Interpretation of correlation coefficient value (r) can be seen in the following table:

Table 3. Interpretation of Correlation Coefficient

\begin{tabular}{|c|l|}
\hline $\begin{array}{c}\text { Correlation } \\
\text { Coefficient }(\mathbf{r})\end{array}$ & Interpretation \\
\hline$>0.90$ & Near Prefect correlation \\
\hline $0.70-0.89$ & Very strong correlation \\
\hline
\end{tabular}




\begin{tabular}{|c|c|c|c|c|c|}
\hline No & Month & \multicolumn{2}{|c|}{$\begin{array}{l}\text { Fishing } \\
\text { Ground }\end{array}$} & $\begin{array}{l}\text { Monthly } \\
\text { Catch/T } \\
\text { on }\end{array}$ & $\begin{array}{l}\text { The } \\
\text { Number of } \\
\text { Trip }\end{array}$ \\
\hline 1 & June & \multicolumn{2}{|c|}{$\begin{array}{l}\text { Southwest of } \\
\text { Aru Islands }\end{array}$} & 46.2 & 15 \\
\hline 2 & July & \multicolumn{2}{|c|}{$\begin{array}{l}\text { South of Aru } \\
\text { Islands }\end{array}$} & 62.2 & 19 \\
\hline 3 & August & \multicolumn{2}{|c|}{$\begin{array}{l}\text { Southeast of } \\
\text { Aru Islands }\end{array}$} & 58.9 & 17 \\
\hline \multicolumn{4}{|c|}{ Total } & 167.3 & 51 \\
\hline \multicolumn{3}{|c|}{$0.50-0.69$} & \multicolumn{3}{|c|}{ Strong correlation } \\
\hline \multicolumn{3}{|c|}{$0.30-0.49$} & \multicolumn{3}{|c|}{ Moderate correlation } \\
\hline \multicolumn{3}{|c|}{$0.10-0.29$} & \multicolumn{3}{|c|}{ Weak correlation } \\
\hline \multicolumn{3}{|c|}{$0.01-0.09$} & \multicolumn{3}{|c|}{ Very weak correlation } \\
\hline \multicolumn{3}{|c|}{0.00} & \multicolumn{3}{|c|}{ No correlation } \\
\hline
\end{tabular}

(De Vaus, 2001)

\subsubsection{Mapping of the Relationship Between the Distribution of Mackerel Catch and The Distribution of Chlorophyll-A And SST}

Mapping of Mackerel catch can be carried out using ArcMap 10.2 software in some steps: (1) Interpolation result of oceanographic parameter value of chlorophyll-a distribution and sea surface temperature value from image that has been cropped based on the research location in the form of monthly average spatial view from June to August in 2015 and the location data of Mackerel catch from June to August in 2015 that has been data-transformed from coordinate point to the spatial layer; (2) Intersecting step for grouping data of Mackerel catch from the highest total of the catch result to the lowest one; (3) Validation data that has been classified into groups with the highest total of the catch result until the lowest one; (4) Layout of the spasial distribution of chlorophyll-a concentration with the total of Mackerel catch and layout of the spasial distribution of SST concentration with the total of Mackerel catch in the form of image in *PNG extension.

\section{RESULT AND DISCUSSION}

Based on the table 4 above, it can be seen that Mackerel catch in June reaches 46.2 ton in 15 trips with catch distribution to the southwest of Aru Islands. The Mackerel catch in July is 52.2 ton in 19 trips with catch distribution to the south of Aru Islands. Meanwhile, in August, the Mackerel catch is 58.9 ton in 17 trips with the catch distribution to the southeast of Aru Islands. This is in line with a statement by Rudiastuti et al (2007) explaining that fishing activity at Arafura Sea in June is more focused on the southeast of Papua. Meanwhile, in July, the fishing activity is more focused on the south of Aru Islands, and in August is on the southeast of Aru Islands.

\subsection{Distribution of Mackerel Catch Result}

Table 4. The spatial and temporal distribution of Mackerel yield from June to August 2015.

\subsection{Distribution of Chlorophyll-a}

Based on the distribution of Chlorophyll-a from June to August 2015, it can be seen that the range of chlorophyll-a content at Arafura Sea in June is $0.30-$ $8.04 \mathrm{mg} / \mathrm{m}^{3}$, while in July is $1.33-5.85 \mathrm{mg} / \mathrm{m}^{3}$, and in August is $1,45-2,36 \mathrm{mg} / \mathrm{m}^{3}$. It can be concluded that chlorophyll-a content at the Mackerel fishing point from June to August is relatively high. Therefore, the Mackerel catch result from June to August is relatively high. It is in line with a statement by Gaol (2006) [1] saying that waters fertility at Arafura Sea is relatively high, that can be seen in the high concentration value of chlorophyll-a, that is, $0.412-18.490 \mathrm{mg} / \mathrm{m}^{3}$ with average of $3.021 \mathrm{mg} / \mathrm{m}^{3}$. According to Afdal and Riyono (2008) [7], waters with chlorophyll-a

\subsection{Distribution of Sea Surface Temperature (SST)}

Based on the distribution of SST from June to August in 2015, it can be seen that the range of SST content at Arafura Sea in June is $26-28^{\circ} \mathrm{C}$, in July is $25-26^{\circ} \mathrm{C}$, and in August is $24-26^{\circ} \mathrm{C}$. Therefore, it can be concluded that the SST content at the Mackerel fishing point from June to August is relatively cold. As a result, the Mackerel catch result from June to August is relatively high.

It is line with a statement by Gaol (2006) [1] explaining that monthly or annual average distribution pattern of SST at Arafura Sea is clearly seen. SST around the sea decreases in dominant temperature value around $26-28^{\circ} \mathrm{C}$ in June. The next month, SST decreases and reaches the lowest value, that is, around $24-26^{\circ} \mathrm{C}$ in August, and lasts until October. Therefore, it makes the waters fertility at Arafura Sea is quite high.

\subsection{Relationship of Chlorophyll-a towards Mackerel Catch Result}

The following result shows the quadratic polynomial analysis between chlorophyll-a and the Mackerel catch result presented in Picture 1

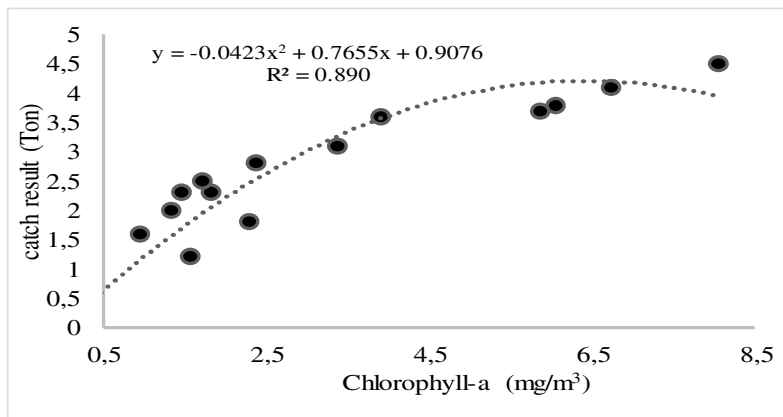

Fig 1. Relationship between Chlorophyll and the Mackerel catch result from June to August in 2015. 
Based on the quadratic polynomial analysis between chlorophyll-a and Mackerel catch result (Fig $1)$, determination coefficient value obtained $\left(R^{2}\right)$ is 0.890 , meaning that $89 \%$ of chlorophyll-a influences the Mackerel catch result at the Arafura Sea. Meanwhile, the highest correlation coefficient value ( $r$ ) is 0.934 , it is shown that the relationship between chlorophyll-a and Mackerel catch result is strong. On the polynomial graph, it is seen an upwardly higher line indicating that the higher chlorophyll-a is, the more Mackerel catch result will increase at the Arafura Sea. It is in line with a statement by Masturah et al (2014) [8] saying that the increase of chlorophyll-a and Mackerel catch result is related to the level of water fertility that supports the life of Mackerel.Map of spatial relationship between Mackerel catch result and the distribution of chlorophyll-a from June to August in 2015 is as follow:
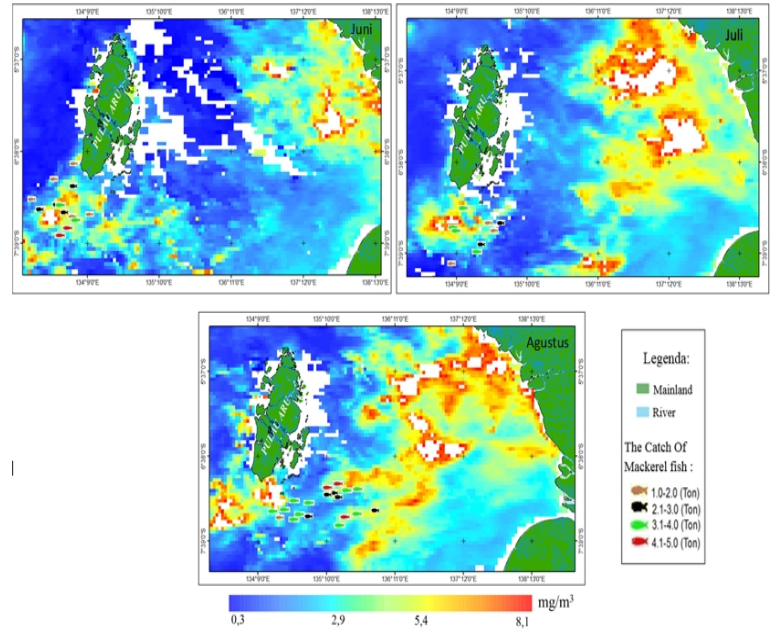

Fig 2. Map of spatial relationship between Mackerel catch result and chlorophyll-a distribution from June to August in 2015

Based on the relationship between Mackerel catch distribution and chlorophyll-a distribution from June to August in 2015 (Picture 2), it can be seen that Mackerel catch result in June is 2-3 ton/day while its chlorophyll-a distribution is $0.30-8.04 \mathrm{mg} / \mathrm{m}^{3}$ with catch distribution to the southwest of Aru Islands. In July, Mackerel catch result is 2-3 ton/day and its chlorophyll-a distribution is $1.33-5.85 \mathrm{mg} / \mathrm{m}^{3}$ with catch distribution to the south of Aru Islands. Mackerel catch result in August is 3-4 ton/day and its chlorophyll-a distribution is $1.45-2.36 \mathrm{mg} / \mathrm{m}^{3}$ with catch distribution to the southeast of Aru Islands.

\subsection{The Relationship of Sea Surface Temperature towards Mackerel Catch Result}

The result of regression analysis between SST and Mackerel catch result from June to August in 2015 is presented on Picture 3 and Table 6.

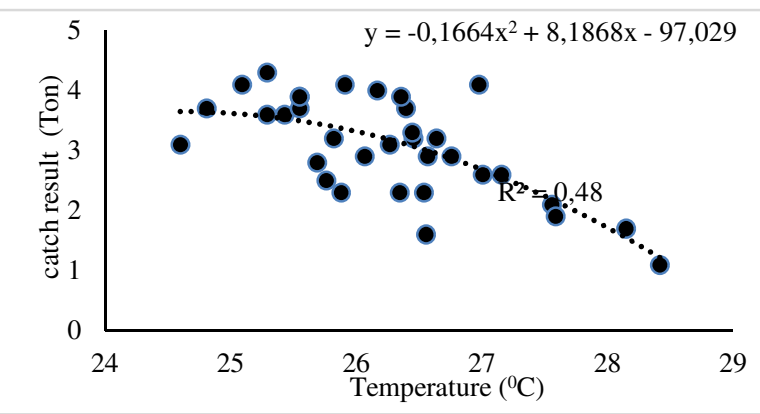

Fig 3. Relationship between SST and Mackerel catch result from June to August in 2015

Based on quadratic polynomial analysis between sea surface temperature and Mackerel catch result on Picture 28, determination coefficient result (R2) is 0.451 , which means that $45 \%$ of SST influences. Mackerel catch result at the Arafura Sea. Meanwhile, the highest correlation coefficient ( $\mathrm{r} 0$ is 0.664, meaning that there is strong relationship between SST and Mackerel catch result. The range of sea surface temperature from June to August in 2015 is $24,6^{\circ} \mathrm{C}-$ $28,4^{\circ} \mathrm{C}$. It is in line with a statement by Masturah et al (2014) [8] saying that optimum temperature of Mackerel ranged $25^{\circ} \mathrm{C}-30^{\circ} \mathrm{C}$.

Map of spatial relationship of Mackerel catch result and the SST distribution from June to August in 2015 is seen below:

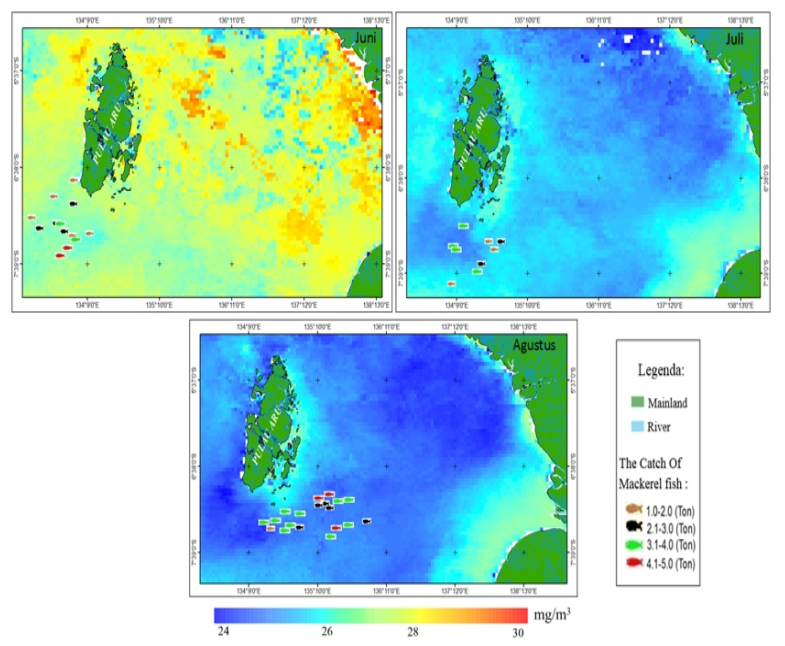

Fig 4. Map of spatial relationship between Mackerel catch result distribution and SST distribution from June to August

Based on the relationship between Mackerel catch result distribution and SST distribution from June to August in 2015 seen on Picture 4, it is shown that the Mackerel catch result in June is 2-3 ton/day and SST distribution is $26-28^{\circ} \mathrm{C}$ with catch distribution to the southwest of Aru Islands. In July, the Mackerel catch result is 2-3 ton/day and SST distribution is $25-26^{\circ} \mathrm{C}$ with catch distribution to the south of Aru Islands. 
Meanwhile, in August, the Mackerel catch result is 3-4 ton/day and SST distribution is $24-26^{\circ} \mathrm{C}$ with catch distribution to the southeast of Aru Islands.

\section{CONCLUSION}

Based on Mackerel catch result distribution from June to August, the highest focus is on August with Mackerel catch result is 62.2 ton in 19 trips, and the catch distribution is to the south of Aru Islands. The range of sea surface temperature from June to August is $24.6{ }^{\circ} \mathrm{C}-28.4{ }^{\circ} \mathrm{C}$, and chlorophyll-a distribution from June to August ranged $0.30-8.04 \mathrm{mg} / \mathrm{m}^{3}$. Regression result shows that correlation coefficient value of chlorophyll towards Mackerel catch result is very strong. Likewise, correlation coefficient value of sea surface temperature towards Mackerel catch result is strong.

Suggestion for the next research is about the importance of further research on potential area to find out the distribution of Mackerel catch at the Arafura Sea.

\section{BIBLIOGRAPHY}

1. Gaol, L.J. 2006. Kondisi lingkungan laut Arafura dari hasil kajian multi sensor satelit. Departemen Pemanfaatan Sumberdaya Perikanan. Bogor. 42hlm

2. Rudiastuti W A, J.L. Gaol, I W Nurjaya. 2007. Distribusi Klorofil-a dari citra MODIS dan hubungannya dengan aktivitas kapal penagkap ikan dari Vessel Monitoring System. Kumpulan Riset Kelautan: Menuju Sumber Daya Alam Yang Lestari. Bogor: Pusat Survei Sumber Daya Alam Laut-BAKOSURTANAL. 274hal.

3. Nurjaya, W.I. 2006. Kondisi Fisik Oseanografi Laut Arafura. Departemen Pemanfaatan
Sumberdaya Perikanan. Bogor. 30hlm

4. Laevastu, T, and M.L. Hayes. (1981). Fisheries oceanography and ecology. Fishing News Books: Farnham. XIV, 199p.

5. Padmaningrat, K.B., I.W.G.A. Karang, dan A.R. As-syakur, 2017. Aplikasi sistem informasi geografis (SIG) dan penginderaan jauh untuk pemetaan daerah penangkapan ikan tuna mata besar di Selatan Jawa dan Bali. J. of Marine and Aquatic Sciences, 3(1):70-83

6. Bender, M.G., G.R. Machado, P.J.A S. de, S.R. Floeter, C.Monteiro-Netto, O.J. Luiz, and C. E. Ferreira. 2014. Local ecological knowledge and scientific data reveal overexploitation by multigear artisanal fisheries in the Southwestern Atlantic. $J$. PLoS One, 9 (10):1-9, DOI: 10.1371/journal.pone.0110332

7. Afdal, S.H, dan Riyono. 2008. Sebaran klorofil-a dan hubungannya dengan eutrofikasi di Perairan Teluk Jakarta. J. Oseanologi dan Limnologi di Indonesia, 34 (3):333-351

8. Masturah, H., S. Hutabarat, dan A. Hartoko. 2014. Analisa variabel oseanografi data Modis terhadap sebaran temporal Tenggiri (Scomberomorus commersoni, Lacépède 1800) di sekitar Selat Karimata. J. Diponegoro Of Maquares, 3 (2):1119.

9. De Vaus, and A. David. 2001. Research Design in Social Research. Sage Publications. London. 298p.

10. Dinas Kelautan dan Perikanan Kabupaten Kepulauan Aru. 2015. Laporan Tahunan Dinas Kelautan dan Perikanan Kabupaten Kepulauan Aru. Dobo. $112 \mathrm{hlm}$

11. Putra, E., J.L. Gaol, dan V.P. Siregar, 2010. Hubungan konsentrasi klorofil-a dan suhu permukaan laut dengan hasil tangkapan ikan pelagis utama di Perairan Laut Jawa dari citra satelit MODIS. J. Teknologi Perikanan dan Kelautan, 3 (2):1-10 